\title{
既設公営住宅へのエレベータ一設置に伴う利便性係数の考察 \\ A STUDY ON THE COEFFICIENT OF CONVENIENCE WITH ELEVATOR INSTALLATION IN THE EXISTING MUNICIPAL APARTMENT-HOUSE
}

\author{
过 壽一*, 藤 田 忍** \\ TSUJI Toshikazu and FUJITA Shinobu
}

\begin{abstract}
Recently, the elevator installation in the existing municipal apartment-house is increasing in Japan. This study focus on the coefficient of convenience according to the elevator installation. As the elevator installation increases, it becomes necessary how to deal with the house the house rentPublic housing law says that the elevator is counted to the point of the coefficient of convenience, and it reflects to the house rent. We investigated the elevator installation and the affairs about the coefficient of convenience also.
\end{abstract}

Keywords : municipal apartment-house, coefficient of convenience, elevator installation, renovation 公営集合住宅、利便性係数、エレベーター設置、リノベーション

\section{1. 研究の背景と目的}

現在、既設の中層公営住宅に対するエレベーター設置工事が日本 各地で行われている。2002 年度、全国のエレベータ一設置工事の実 情を調查した我々の既往研究である「既設公的貸貸集合住における エレベーター設置工事の考察」においても、既設公営住宅に対する エレベーター（以後、EV とする）設置が、今後増加の傾向にあるこ とが分かった。EV 設置に伴って発生する費用としては、(1)EV 設置工 事費と(2)EV 維持管理費がある。

2003 年度の調查から、「既設公的賃貸集合住宅への EV 設置に関す 万研究 (その 3) - EV 設置に伴い発生する費用負担について一」で は、EV 設置に伴う家賃や共益費の值上げについて考察している。そ の中で、EV 保守費については、大半の管理主体がそのほとんどを負 担していたが、居住者の負担を求めている管理主体もあった。また、 EV 保守費の負担内容は管理主体独自の判断で決められており、管理 主体と居住者との負担割合なども管理主体によって様々であること もわかった。次に、現在の公営住宅法の家賃算定基準では、原則と して住戸改善工事以外の工事費を家貨算定に反映させることはでき ないが、家賃算定の係数の一つに利便性係数がある。これは公営住 宅のある区域及びその周辺地域状況の利便性や公営住宅の設備など の利便性を数值化したものである。 EV 設備を新設した場合、この利 便性係数を見直すことで家賃の值上げが可能となる。その数は多く ないが、この利便性係数を見直すことで、家賃の調整を行っている 管理主体があった。また、その利便性係数の設定の方法も管理主体 の独自の方法によって行われていることがわかった。

2000 年度、建設省（現国土交通省）の諮問機関である住宅宅地審 議会から、公共賃貸住宅ストックの新たな活用を目指して「21世紀 の豊かな生活を支える住宅・宅地政策について」の答申がなされた。 その中で特に公営住宅への取り組みとして、居住水準における住
宅性能の水準の設定や住宅ストック改善の推進など新たな住宅政策 の課題に配慮した公営住宅の家賃算定方法について、各事業主体の 家賃の設定状況等を踏まえて検討を行うべき」で、今後のストック活 用方針として、公営住宅ストックをより良質なものとする必要があ るとされており、そのため公営住宅の家賃算定方法も、それを踏ま えた検討を行う必要があるとしている。

本研究は、既設公営住宅に対する $\mathrm{EV}$ 設置事例が増加する中で、 $\mathrm{EV}$ 設置に伴う家賃・共益費の值上げの実情と家賃算定に係わる利便性 係数の設定、また、EV が未設置の場合における利便性係数設定の実 情について調查・考察している。

\section{2. 調查の方法}

全国 3009 の地方公共団体のうち義務的建築主事を置く特定行政 庁（2004 年 4 月 1 日現在、東京都の場合は特別区を含む）および、 公営住宅を管理している 2 住宅供給公社の計 269 管理主体人「既設 公営住宅における EV 設置に関する調查」と題したアンケート調查 （2004 年 8 月〜11 月）を行った。2002 年度に「公的集合住宅にお ける $\mathrm{EV}$ 設置の改修工事に関寸る調查」、2003 年度においては「公的 貨貸集合住宅における $\mathrm{EV}$ 設置の実態に関する調査」を行い、全国で EV の設置実績もしくは設置計画をもつ管理主体を対象にアンケー 卜調査を行ってきた。2004 年度はさらに調査の対象を広げ、全国の 特定行政庁に対しアンケート調查を行った。なお、既設集合住宅へ の EV 設置事例のほとんどすべてが公営住宅であるため、本研究にお いては調查の対象から公社・公団を除外している。ただし、公共団 体から公営住宅の管理を委託されている東京都住宅供給公社、愛知 県住宅供給公社は調査の対象とした。以上 269 管理主体（都道府県 47、市区 220、公社 2) に送付し、211 管理主体 (都道府県 39、市区 171、公社 1）の回答を得た。回収率は $78.4 \%$ でった。 


\section{3. 公営住宅の家貨算定方法と利便性係数}

公営住宅の家貨算定方法は以下の式で求められる。

*家賃 $=$ 家賃算定基礎額 $\times$ 市町村立地係数 $\times$ 規模係数 $\times$ 経過年 数係数 $\times$ 利便性係数

家賃算定基礎額は、入居者の収入に忘じて設定されるもので全国 統一の額である。市町村立地係数は、国土交通大臣が $0.7 \sim 1.6$ まで の範囲内で市町村ごとに定める数值である。規模係数は、当該公営 住宅の床面積の合計を $70 \mathrm{~m}^{2}$ で除した値をいう。経過年数係数は、公 営住宅の老朽化によって決められる。そして、利便性係数は事業主 体が当該公営住宅の存する区域およびその周辺の状況、当該公営住 宅の設備等を勘案して、0.5 1.3 の範囲内で設定するものである。 このうち、経過年数係数の算定式と利便性係数の範囲は 2004 年 (平 成 16 年) に改正されている。原則として、住戸改善工事がある場合 を除き、既設建物への EV 設置で家賃の值上がりが予想されるのは、 利便性係数の変更が主要因だと考えられる。

特に、EV 設置によって利便性が向上する点としては、従前の階段 歩行からバリアフリー化への対応だと考えられる。

各管理主体の利便性係数の対象とする項目を聞いた（複数回答）。 188 管理主体 (89.1\%) が「住戸の浴槽、給湯設備などの有無」と し、その他の項目を大きく上回る結果となった。続いて、「EV 設備 の有無」92 管理主体 (43.6\%)、「下水道設備の有無」となっている。 また、周辺の状況では、「最寄駅の近接性」58 管理主体 (27.5\%)、「教 育施設、郵便局・銀行などの近接性」、住宅が存する地域の固定資 産税評価額」などがあったが、家貨の算定に当該住宅の立地条件な どはそれほど考慮されていないことがわかる（図 1)。

「住戸の浴槽、給湯設備など」という住生活の基本となる設備の 設置有無が利便性係数算出の最も大きな要素となっていることは、 現在の公営住宅ストックにおいて、いまだ設備面での居住水準が一 般住宅と較べて劣る部分が多いことが推察される。また、「EV 設備 の有無」を利便性保数の対象項目としている管理主体は 92 管理主体 （43.6\%）であることは、逆に EV 設備の有無を利便性係数に考虑し ていない管理主体が 119 管理主体 (56.4\%) と半数以上にのぼること を意味し、EV 設備の利便性についてその考え方が大きく 2 分されて いることがわかった。

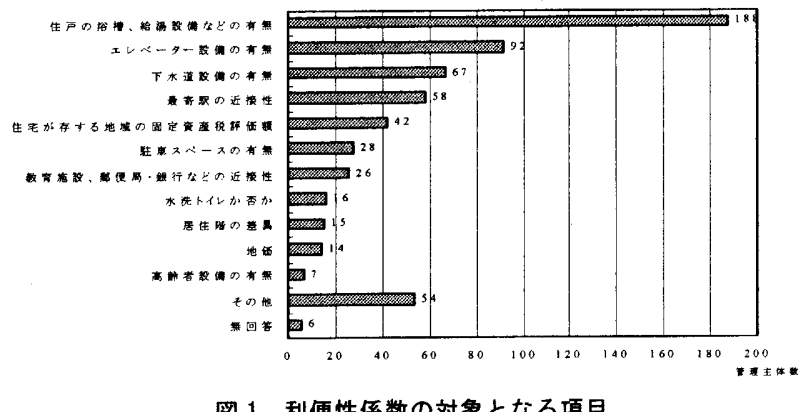

次に、15 管理主体 (7.1\%) が利便性係数の対象項目として「居住 階の差異」をあげているが、上下階による階段歩行の差を利便性係 数の対象と考えている管理主体は極めて少ないことがわかる。

\section{4. 居住階による利便性係数の設定}

EV 設置の有無にかかわらず居住階によって利便性係数に差異を
設けたことがあるかを聞いた（図 2)。18 管理主体（8.5\%）が居住 階によって利便性係数に差を設けたことがあり、188 管理主体 （89.1\%）がないと回答している。利便性係数に差を設けたことがあ る 18 管理主体のうち、EV 設置の計画や実績がある管理主体とない 管理主体の割合はそれぞれ 9 管理主体で同数であった。また、利便 性係数に差を設けたことがない188 管理主体のうち、EV 設置の計画 や実績がある管理主体は55管理主体で、計画や実績がない管理主体 は 133 管理主体に上っていた。概衫管理主体は居住階により利便性 係数に差異を設けることをそれほど考慮していないように思われる。 しかし、利便性係数に差を設けている 18 管理主体のうち 13 管理主 体が、前節で利便性係数の対象項目として「居住階の差異」をあげ ている。「居住階の差異」を利便性倸数の対象項目としているほとん どの管理主体が、実際の家賃算定にそれを反映させている。
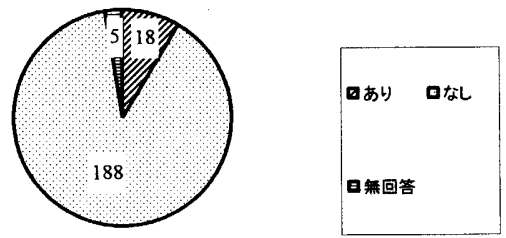

因 2 階による利便性係数の差を設けたこと のある管理主体の有無 （母数：211）

現在、EV 設置の計画や実績を持たないが、居住階によって利便性 係数に差を設けている管理主体が 9 管理主体あった。それらのほと んどは、EV が設置されていない住棟の上層階（概ね 4 階以上）の家 賃を低層階より安く設定していた。これらの管理主体は、上層階へ の階段歩行は、低層階住戸に較べ利便性に劣ると判断している。

\section{5. 居住階による家貨の差異について}

次に、あらたに EV を設置する場合、居住階によって家賃の差異を 設ける必要があるかを聞いた。28 管理主体（13.3\%）が必要である としており、176 管理主体 (83.4\%) が必要ないと回答した（図 3-1）。

ほとんどの管理主体が、居住階によって家貨の差を設けるべきで はないと考えているが、設けるべきであるとした管理主体も少なか らずあることがわかる。また、現在すでに差異を設けている管理主 体の中でも、居住階による差異は不必要であると回答している管理 主体が 2 あり、現在差異を設けていない管理主体の中にあっても、 必要であると回答した管理主体が 12 あることから、管理主体がこの 判断に苦慮している面があることがわかる（図 3-2、3-3）。

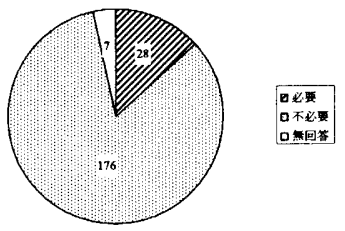

図 3-1 居住陌による利便性係数の差異 （母数: 211）
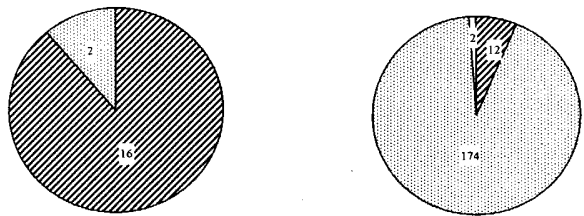

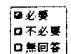

図 3-2 差異を設けている管理主体 図 3-3 差異を設けていない管理主体 
上層階・低層階の違いによって家賃の差を設けるべきではないと した 176 管理主体にその理由を聞いた（複数回答）。

「これまで上層階・低層階で差異を設けていないため、EV 設置後 も差を設けないのが当然である」100管理主体 (56.8\%)が最も多く、 「居住者の合意が得にくいから」49 管理主体 (27.8\%)、「どのよう に差異を設ければいいのかわからないから」47管理主体 (26.7\%) となった。その他のなかでは、「低層階と上層階の差異は主観で、係 数に反映することは適当でないから」、「公営住宅の観点から公平で ないから」、「入居者に居住階の選択権はないから」など 10 管理主体 （5.7\%）の意見もあった（図 4)。また、「利便性係数の設定項目を 細分化することにより複雑な家賃体系となる」ことから家賃の差を 設けていないという管理主体もあった。

以上の内容は、住民サービスを基本とする公営住宅の通常の考え 方として理解できる。ただ、「居住者の合意が得にくいから」とした 管理主体と、「どのように差異を設ければいいのかわからないから」 と回答した 47 管理主体を重複する 9 管理主体を除いて合計すると 87 管理主体 (49.4\%) となった。このことは、上層階・低層階の違 いによる家賃差を設けるべきでないとした管理主体にあっても、そ れに対するそれほど明確な理由を有していないことがうかがえる。

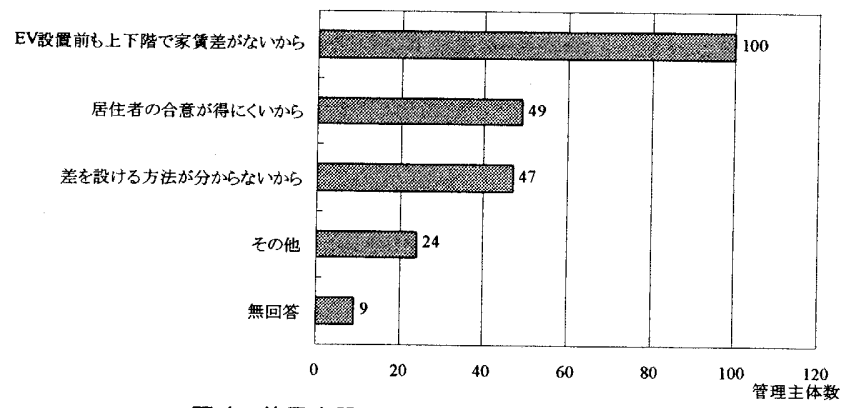

图 4 差異を設ける必要がない理由（母数:176）

次に、上下階で家貨の差を設けるべきとする 28 管理主体にその 理由を聞いた（複数回答）。

最も多いのが、「利用頻度によって応分の負担をす心゙きだから」 で 9 管理主体 (33. $3 \%) 、$ 次に「居住者間の合意が得やすいから（低 層階の居住者の合意が得やすい)」が 8 管理主体 (29.6\%)、その他が 12 管理主体（42.9\%）であった（図 5)。

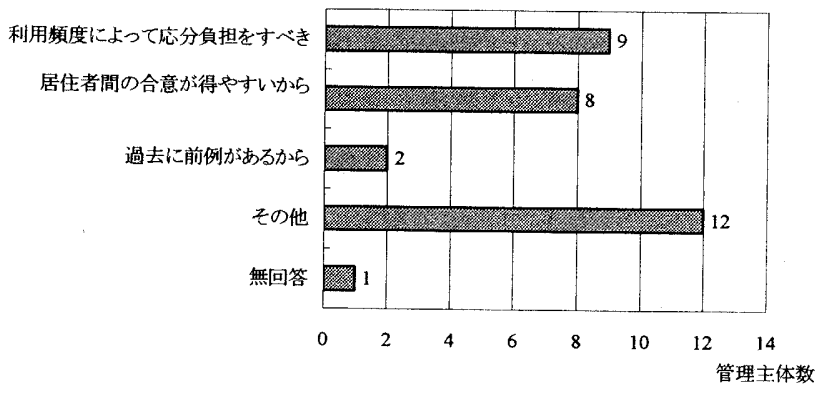

図 5 差異を設ける必要がある理由（母数：176）

上下階で家賃の差を設けるべきとした 28 管理主体のうち、(1)EV を設置することにより、上層階の利便性が増すことで上層階の家賃 を低層階より高く設定すべきだと考えている管理主体と、反对に、 (2)EV が末設置の場合では低層階に較べて上層階が利便性に劣るた め、低層階に較べて上層階の家貨を低くすべきだと考えている管理
主体とに分かれた。

まず、EVを設置することで上層階の家賃を低層階より高くすべき だと考えている管理主体があり、その主な理由として「利用頻度に よって応分の負担をすべきだから」と「居住者閒の合意が得やすい から（低層階の居住者の合意が得やすい）」をあげており、重複を除 くと 12 管理主体 (42.9\%) であった。またその反対に、EVが未設置 の場合では、低層階に較べて上層階の家賃を低くすべきだと考える 管理主体が 16 管理主体 (57.1\%) であった。そして、EVの設置後は 上層階の家賃を值上げし、低層階と同じにすべきであるとしていた。 それらの管理主体の判断は「低層階に較べて上層階は利便性に劣る ため」で、各管理主体で概ね同一であった。

このように、 $\mathrm{EV}$ 設置後の上下階家貸算定の考え方について、管理 主体により異なる考え方をもっていることがわかる。

さらに、EVの設置によって上層階の家貨を低層階より高くすべき とした 12 管理主体で、EV 設置の実績・計画をもつ管理主体は 4 管 理主体で、実績・計画をもたない管理主体は8 管理主体であった。 また、EV が未設置の場合、低層階に較べて上層階の家賃を低くすべ きだと考えている 16 管理主体のうち、EV 設置の実績・計画をもつ 管理主体は 7 管理主体で、実續・計画をもたない管理主体は 9 管理 主体であった。このことから、具体的な $\mathrm{EV}$ 設置の実績・計画の有無 に関倸なく管理主体の判断が分かれており、また、実際の具体的な $\mathrm{EV}$ 設置事例において、管理主体によって異なる考え方での家賃算定 が行われている。

\section{6. 上下陧による共益費の差異について}

$\mathrm{EV}$ 設置の場合、相当の維持管理費が新たに必要となる。既往研究 では、EVのメンテナンス費用は管理主体の全額負担が多いこと、そ して、EV の使用電気代は共益費として居住者が全額負担している場 合が多いことがわかった。

各管理主体に上層階・低層階で共益費に差異を設ける必要がある かを聞いた。10 管理主体 (4.3\%) が必要であるとし、180 管理主体 (85.1\%) が必要ないとしている（図6）。

共益費に差を設ける必要はないとする理由では、「これまで上層 階・低層階で差異を設けていなかったから」107 管理主体 (59.4\%)、

「居住者の合意が得にくいから」55 管理主体 (30.6\%)、「どのよう に差異を設ければいいのかわからないから」40管理主体 (22.2\%) であった。一方、共益費に差を設ける必要があると回答した管理主 体は、「利用頻度によって忘分の負担をすべきだから」6管理主体 （66.7\%）という回答が多く見られた。また、共益費については団 地自治会に一任しており管理主体はその内容に関与しないという管 理主体が 21 あった。

通常、公営住宅の共益費の範囲は主として共用部の電気代などの 光熱費や水道料金などで、それらは基本的に居住者負担となってお り、その費用はそれほど大きなものでないため、具体的な負担内容 などは団地自治会や居住者自身で決められることが多い。ただ、新 たに EV 設置した場合、従来とは異なって相当の維持管理費が発生 し、しかもその費用は従来の共益費と較べてかなり高額となる。EV のメンテナンス費用を今後とも管理主体の全額負担とすれば特に問 題とはならないが、その場合、EVの設置台数の増加によって管理主 体の支出が毎年増えることが予想される。今後、全国の $\mathrm{EV}$ をもたな 
い既設公営住宅への EV 設置が進めばその費用はますます增大する ものとなる。したがって、EVメンテナンス費など維持管理にかかわ る費用については、居住者負担を検討することもひとつの課題であ るといえる。EV 設置の実績・計画をもつ管理主体は全国で 66 管理 主体に上るが、事実、そのメンテナンス費用を全額居住者負担とし ている管理主体も存在している（図 7)。

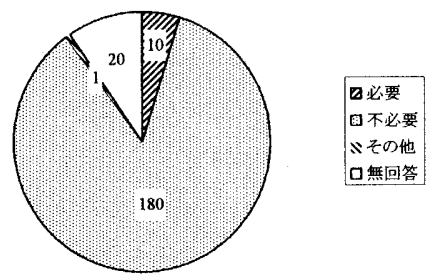

图 6 上低層陼によって共益費に差異を設ける必要性

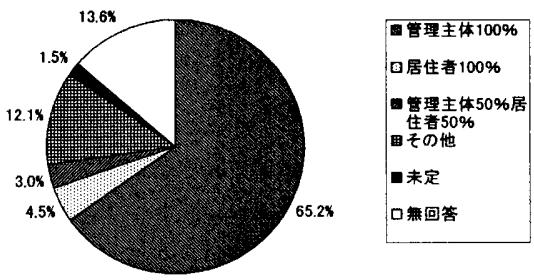

図 $7 \mathrm{EV}$ メンテナンス費の負担割合（母数:66）

\section{7. 利便性係数に差異を設けた事例}

「4. 居住階による利便性係数の設定」で、居住階により利便性 倸数に差異を設けている管理主体は 18 管理主体であった。ほとんど の管理主体は、家賃の算定方法が変更となった 1996 年（平成 8 年） の公営住宅法改正 (適用は 1998 年度より) 時に、管理している公営 住宅全体の家貨を見直している。その手法は、EVのない住棟におい ては居住階による利便性に差があるとして、利便性倸数に差異を設 けていた。以下、現状の利便性保数の設定区分を 6 種類に分類した。

1） $1 \cdot 2$ 階、3.4.5 階の 2 区分（2管理主体）

上層階（3、4、5 階）の利便性が低層階（1、2 階）より劣るとし て係数を低く設定している。その差異は 2 管理主体とも0.01 であっ た。そして、EV の設置後は上下階とも利便性が同等になるとして係 数を全戸同一としている（図 8)。

この区分方法は、一般的な低層住宅 $(1 \cdot 2$ 階) と中層住宅 (3.4.5 階）の区分が反映されていると推察できる。

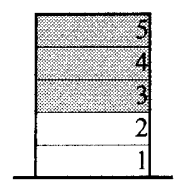

$\mathrm{EV}$ 設置

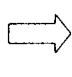

国和便性保数の設定防分

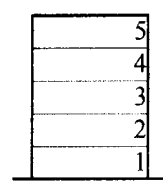

EV 設置
图 8 利便性係数の設定区分（1-2 階、3.4.5 階）

2) $1 \cdot 2 \cdot 3$ 階、4.5 階の 2 区分（8 管理主体）

上層階（4、5 階）の利便性係数を低層階（1、2、3 階）より低く 設定している。その差異は 0.01〜0.03 程度であった。そして、EV の設置後は、係数を $1 \cdot 2 \cdot 3$ 階の利便性係数に統一される（図 9)。 この設定区分をしている管理主体がもっとも多い。公営住宅ストッ ク総合改善事業補助金交付要網において、全面改善事業とするには、
共用部分改善で 4 階以上の EV が未設置の住棟に対し、EV を設置す る必要があるとされている。したがって、この区分方法はこのよう な全面改善事業の考え方に基づいていると思われる。

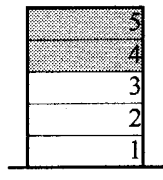

EV 設置

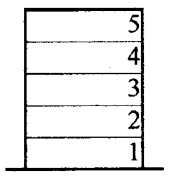

EV 設置
图 9 利便性係数の設定区分 $(1 \cdot 2 \cdot 3$ 階、4.5 階)

3) $1 \cdot 2 \cdot 3 \cdot 4$ 階、5 階の 2 区分（1 管理主体）

公営住宅法改正時に、EV が未設置の住棟に対して 1 4 階と 5 階 の 2 段階にわけて、5 階の利便性係数を $1 \sim 4$ 階にくらべ低く設定し ている。EV の設置後は上層階の係数を低層階に統一している(図 10)。

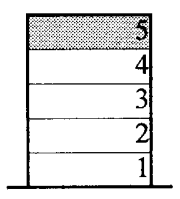

EV 設置前
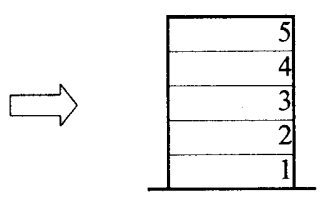

$\mathrm{EV}$ 設置後
図 10 利便性保数の設定区分 $(1 \cdot 2 \cdot 3 \cdot 4$ 階、5 階)

4) $1 \cdot 2 \cdot 3$ 階、4 階、5 階の 3 区分（3 管理主体）

利便性係数を、1・2・3 階、4 階、5 階の 3 段階に設定している。 その差異は 1 管理主体の場合 $1 \cdot 2 \cdot 3$ 階 $\pm 0 、 4$ 階 $-0.02 、 5$ 階 - 0 . 03 としている。また別の 1 管理主体は EV の設置計画がないため、 $\mathrm{EV}$ 設置が行われた場合の見直しは不明ということであった(図 11)。

この区分方法は、基本的に 2）と同じく全面改善事業の考え方に 基づいているが、4 階と 5 階についても倸数をわけることで階段歩 行の負担の実情に即したより厳密な区分をしていると考えられる。

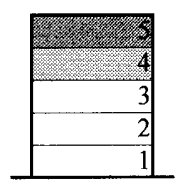

EV 設置前

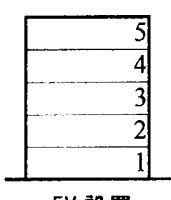

$\mathrm{EV}$ 設置

図 11 利便性係数の設定区分 $(1 \cdot 2 \cdot 3$ 階、4 階、5 階)

5 ） 1.2 階、3 階、4 階、5 階の 4 区分（1 管理主体）

利便性係数を 1.2 階、3 階、4 階、5 階の 4 段階に設定している。 その差異は $1 \cdot 2$ 階士0、3 階-0.005、4 階-0.010、5 階-0.015 で あった。現在、管理主体では EV 設置の実績、計画はないが、今後 EV 設置が行われた場合は $1 \cdot 2$ 階の係数に統一寸るとしている（図 12）。この区分方法は、1）の区分方法に準じているものの 4）と同 様、より厳密に実際の歩行距離の違いを反映させているといえる。

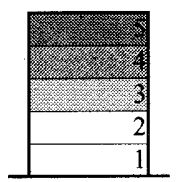

EV 設置前

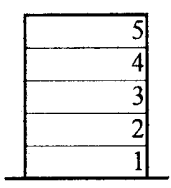

EV 設置後

図 12 利便性係数の設定区分 $(1$-2 階、3 階、4 階、5 階) 
6） 1 階、2.3 階、4.5 階の 3 区分（3 管理主体）

利便性係数を 1 階、 $2 \cdot 3$ 階、4.5 階の 3 段階に設定している。1 管 理主体において係数の差異は、1 階 $\pm 0,2 \cdot 3$ 階 $-0.0050 、 4.5$ 階 -0.0100 としている。EVの設置後は、係数を 1 階に統一している(図 13-1)。

この区分方法は、住戸までの階段歩行の点において、1階はその 他の階と較べて大きく異なると判断されていることがわかる。つま り、1 階においては階段歩行がほとんどないとし、上層階は歩行距 離を勘案した設定区分がなされていると考えられる。高齢者などに とって、1 層分の階段歩行も負担となる場合もあるとする管理主体 の判断が推察できる。

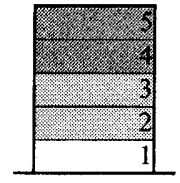

EV 設置前

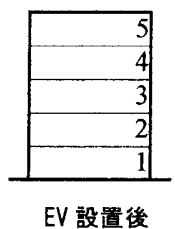

図 13-1 利便性俰数の設定区分（1 階、2.3 階、4.5 階）

他の 1 管理主体の場合は、今までの設定方法とは異なっている。 管理する既設高層住棟においては利便性係数が 1.2 階、3.4 階、5 階、6 階以上の 4 段階に分けられており、係数は上層階ほど高く設 定されている。そして、EVをもたない既設中層住棟の利便性係数は 階数によって 1 階、 $2 \cdot 3$ 階、 4.5 階の 3 段階に分けられ、上層階にな るほど利便性係数を低く設定している。そして、EV 設置後は高層住 棟の倸数設定に準じて $1 \cdot 2$ 階、3.4 階、5 階の 3 区分となる(図 13-2)。 この事例においては、EV を設置することで、上層階の家賃が下層階 よりも高くなっている。この管理主体は、すでに EV が設置されてい る住棟において上層階の利便性係数を低層階より高く設定している。 つまり、EV は上層階居住者のためのものであり、居住者の階段歩行 という負担については考慮されていないが、EVをもたない住棟につ いてはそれが考虑されている。

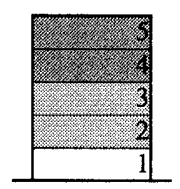

EV 設置前

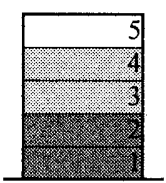

$\mathrm{EV}$ 設置後
図 13-2 利便性係数の設定区分（1 階、2-3 階、4-5 階）

$\mathrm{EV}$ が未設置の住棟において、上下階で利便性係数に差異を設けて いるほとんどの管理主体は、EV 設置後は 1 階もしくは低層階と利便 性が同等になったとし、上層階と低層階の利便性係数を同じとして いる。つまり、EVを設置することで上層階の家賃を值上げし、1 階 と同じ額にしていた。総じてこれらの管理主体は、1996 年の公営住 宅法改正時に家賃の見直しを行った際に EV が未設置の住棟の上下 階で利便性保数を変更している。したがって、現在 EV が未設置の既 設住棟において、上下階で利便性係数の差異を設けていない管理主 体は当然この手法をとることはできないことになる。また、現法下 で改めて家賃の見直しを行うことについては住民合意などの問題が 残るといえる。注目す心゙き点として、EVが未設置の住棟で上層階の 利便性倸数を低層階のそれより低く設定していることは各管理主体 で基本的に同一であるものの、階による倸数設定の方法が管理主体
によって異なり、一定ではないという点である。つまり、階による 利便性係数の設定に一般的な基淮がなく、管理主体独自の判断で決 められていることがうかがえる。また、EV を設置することで上層階 の家貨を下層階のそれより高くしている管理主体もあった。

\section{8. 終わりに}

EV の設置による家賃の値上げに対する居住者の反対があり、住民 の合意形成に苦慮したという管理主体の意見が多数聞かれた。居住 者にとって、家賃や共益費の值上げは大きな問題である。したがっ て、それら居住者の合意形成にとっての障害となるような点に対し、 管理主体としてある程度共通する基本的な認識が必要だと考える。 1）EVをもたない住棟に対し新たに EV を設置する場合の家賃につ いて、EVの設置は劣る利便性の解消であると判断できる。したがっ て、原則として $\mathrm{EV}$ 設置後における利便性係数はすべての階で同一と なるようにすべきであると考えられる。

2) しかし、上記 1 ）の内容から、現在 EVをもたない住棟において 上下階で利便性係数に差異を設ける必要が生じ、上層階の家賃を下 層階のそれより低く見直すことが求められる。ただ、このことは現 在、上下階において利便性倸数に差を設けていない管理主体が大半 であるため、改めて家賃を見直す場合その影響は多大なものとなる ことが予想される。したがって、これには慎重な検討が求められる。 3）また、上記 2）の場合、住棟の上下階でどのような利便性係数 を設定することが合理的であるかの検討が必要だと考えられる。

前節の事例から、EVをもたない住棟の上下階における利便性係数 に差異を設けている管理主体の判断は、上階への階段歩行は利便性 に劣るとする点は共通しているが、その設定方法は多様であった。

7.5）の事例のように、係数を階によって細かく分類することは合 理的だと考えられるものの、その家貨算定作業は煩雑なものとなる。

今後、EVをもたない住棟の家貨全体を改めて見直す必要性の有無 も勘案する必要はあるが、居住階によって異なる利便性係数を設定 する場合、より慎重な検討が必要だといえる。

\section{謝辞}

本研究にあたり、お忙しい中ご協力いただいた全国の管理主体の 皆様、ご担当者に梁く感謝申し上げます。また、共同研究者である 大阪市立大学生活科学研究科前期博士課程中村岳氏に心より謝意を 表します。

\section{参考文献}

1）梶浦編著：分譲マソションの管理 - 居住の学からの7プローチ、彰国社、1997.10

2）辻 壽一、藤田忍：既設公的賃貸集合住におけるエレベーター設置工事 の考察一階段室型エレベーターを中心として一、日本建築学会計画系論文 集第 580 号、2004.6

3）国土交通省：21 世紀の豊かな生活を支える住宅・宅地政策について、住 宅宅地審議会答申、2000.6

4）日本住宅協会：公営住宅必携平成 15 年度版 国土交通省住宅局住宅総合 整備課監修 2004.2

6）木本善文、藤田忍、辻尋一、中村岳 : 既設公的供貸集合住宅へのエレベー タ一設置に関する研究（その3）一EV設置に伴い発生する費用負担につい $\tau$ 一、日本建築学会大会学術講演梗概集 F-1 分冊、2004.8 